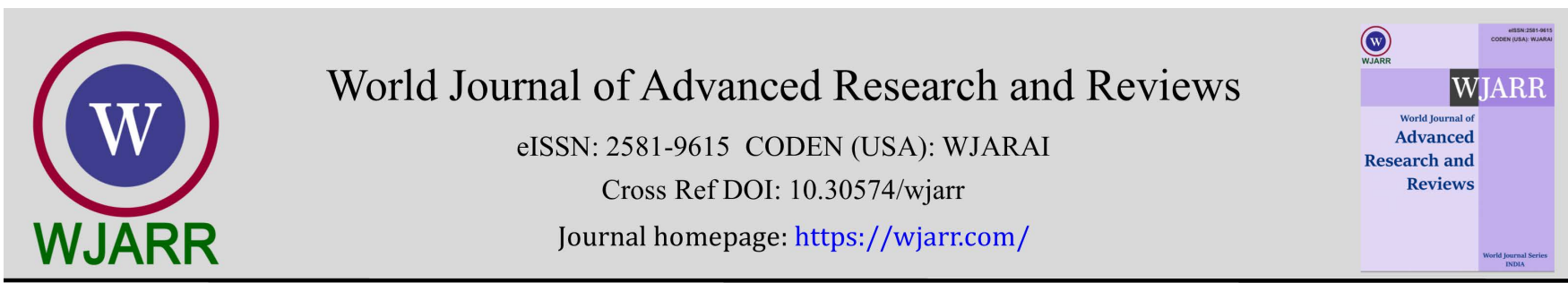

(RESEARCH ARTICLE)

Check for updates

\title{
The impact of wood cutting and of bush fires on the dynamics of the herbal strata of Sudano-Guinean Savanna
}

Ranava Dieudonne 1,3,*, Tchobsala 1, Ibrahima Wanie Sago 1, Massai Tchima Jacob 1,3, Godwé Gara JM 1,3, Ibrahima Adamou ${ }^{1}$ and Mbolo Marie ${ }^{2}$

1 University of Ngaoundere, Department of Biological sciences, Faculty of Sciences. Laboratory of Biodiversity and sustainable development. P.O. Box: 454, Cameroon.

${ }^{2}$ University of Yaoundé I, P.O. Box: 812, Cameroon.

${ }^{3}$ Institute of Agricultural Research for Development (IRAD), P.O. Box 65 Ngaoundere, Cameroon.

World Journal of Advanced Research and Reviews, 2021, 10(03), 334-347

Publication history: Received on 17 May 2021; revised on 20 June 2021; accepted on 23 June 2021

Article DOI: https://doi.org/10.30574/wjarr.2021.10.3.0284

\begin{abstract}
Few studies were carried out on the impact of wood cutting and bush fires on the dynamics of the herbal strata in savannahs of Adamawa, Cameroon. This study has as objectives to evaluate: 1 . the recovery of the vegetation of shrub and grass savanna, 2. the evolution of the number of herbs with regards to time, 3 . the floristic and specific contribution of the herbal specie. The inventories of herbaceous plants were carried out through quadra method in 9 sub-plots of 10 $\mathrm{m} \times 10 \mathrm{~m}$ for each vegetal formation. The experimental design was split-plot with two (02) factors (savanna trees and shrubs), three (3) treatments (felling without fire, with fire and witness) and three (3) rehearsals/repetitions (portions). The analysis of variance (ANOVA) was used to compare means between treatments by using STATGRAPHIC XVII, and XLSAT to obtain result shown that 103 herbaceous plants divided in 73 genres and 23 families. The rate of recovery of savanna vegetation the herbs are more numerous $60 \%$ in the CSF, $50 \%$ in the CAF and $45 \%$ in witness site (wood savanna), Adversely, $30 \%$ in a witness site, $40 \%$ in the CSF and $50 \%$ in the CAF (shrub savanna). The number the species have grown from 3 to 45 in the tree's savanna and 2 to 34 for the shrub savanna. The specific contribution of herbaceous varies according to the sites and the species.
\end{abstract}

Keywords: Wood cutting; Bushfire; Savanna; Dynamics herbal strata and Bini

\section{Introduction}

Increase of population and overuse of natural resources are main cause environmental degradation. This degradation is manifested by the erosion of the biodiversity, fragmentation of huge forests, the decreased of soils fertility [1, 2-3]. The vegetation of sub-Saharan Africa in general and those of Cameroon in particular is confronted with deforestation which is manifested by the unforeseen increase in the research for natural resources [4]. Environment in all its diversity is at the same time a type of space of life necessary and delicate for the long-lasting existence of human beings. This anthrophic pressure of the plants cover is responsible for the degradation of soils and for climatic change [5] thus; space will be in danger considering that its exploitation is at the same time illegal and unlawful. Beyond international preoccupations in matters of sustainable development [6], the questions on the degradation of these forests and of ecological extinction of resources constitute the interest of our study. The savannas are fragile ecosystems reposing on the coexistence between the herbal strata and the ligneous strata, they constitute the dynamic systems who's the evolution depends on the intensity of environmental factors (felling/cutting, drying, fire, rearing and agriculture). The

\footnotetext{
${ }^{*}$ Corresponding author: Ranava Dieudonne

University of Ngaoundéré, Department of Biological sciences, Faculty of Sciences. Laboratory of Biodiversity and sustainable development. P.O.Box: 454, Cameroon.
}

Copyright (C) 2021 Author(s) retain the copyright of this article. This article is published under the terms of the Creative Commons Attribution Liscense 4.0. 
conditions of their persistence are very complex and remained poorly known. They have constituted the topic of numerous researches. [7, 8- 9] that compete to conclude the majority is maintained in its state by fires and as a result, are considered as non-climatic. This situation coupled with the climatic change of these last ten years extreme poverty in the rural populations [10]. As concerns the felling of trees and bushfires causing deforestation, these two concepts have a relation of cause and effect and being capable of provoking climate change. Their pressure on ecosystems in the Sudano-guinean zone increases progressively with the strong increase in the population, this demographic explosion leads to the increasing pressure on the natural ecosystems [11, 12-13].

The savannas are particularly exposed to important risks of degradation in so far as that the major part is located in the arid and semi-arid zones and shelters an important part of the world population [14]. A part from their importance from the agricultural, ecological, and environmental point of view the question of durability represents a major stake [15, 1617] which is worth studying. In situations of reasoning, the role of bushfires in the dynamics of the regeneration of the vegetation of savannas has not yet been well established especially as it concerns the method of use of these fires. Bushfires can cause the upsetting of bio-geographical cycles of the vegetation, that can lead to negative and or positive impacts on the production of natural ecosystems. These fire impacts were known since a long time by the scientific community [18].

In this Sub division, tree felling and bushfires remains a real threat to the protection of natural resources. These savannas undergo strong anthropic pressures such as deforestation, the over pasturing and above all bushfires like in the high Guinean savannas of Cameroon [19].

Relying on this observation, we question the modalities of the sustainable use and management of the vegetation coverage of the ecosystems. The study of the correlation between 'felling, fire, dynamics of regeneration of the vegetation permits to say that even if the fire is recognized as a factor of explanation of the dynamics of the vegetation of savannas, its importance and its role are not always well defined [9].

Besides, the reflexion begun in the logic of this research is a rich investigation which causes so many scientific domains to intervene. It is for that reason that so many research works (thesis, texts, dissertations, articles, reviews) are consecrated to it. It is a question for instance of studies carried out by [20] on the study of the dynamics of a shrub savanna in the Sudano-guinean zone of north Cameroon under the combined effects of pasture, from fire and of the felling of trees; [21] on the regeneration of trees, dynamics of the vegetation and the maintenance of biodiversity in Mount Cameroon; [22] in Senegal on the dynamics of the natural regeneration of the vegetation and [19] on the impact of tree felling on the natural vegetation on the peri-urban zone of Ngaoundere. However, no work has been carried out on the impact of the complex felling of trees and bushfires on the dynamics of the regeneration of the vegetation of savannas in the locality of Bini and Dori who are strongly damaged by the uncontrollable felling of trees.

The main aim of this work is to study the impact of felling of trees and bushfires on the dynamics of the herbal strata. It is specifically a question of; 1 ) evaluate the recovery of the vegetation of shrubs and tree savannas, 2) know the evolution of the number of herbs according to the time, 3) do the grouping of herbal species in the different vegetation formations and at last 4) determine the floristic composition, the centesimal frequency and the specific contribution of herbal species.

\section{Geographical location}

Situated in central Africa and in the north of Cameroon, the Cameroonian Adamawa is a region located between $6^{\text {th }}$ and $8^{\text {th }}$ degree latitude North and between $10^{\text {th }}$ and $16^{\text {th }}$ degrees longitude East. It spreads on an area of about $62000 \mathrm{~km}^{2}$, on altitudes made up of between 900 and $1500 \mathrm{~m}$. Its climate is the Sudano-guinean type with an annual pluviometer/rain gauge of between 1600 and $1800 \mathrm{~mm}$, spread on 7 to 8 months. The annual average temperature is $23^{\circ} \mathrm{C}[23,24]$. The High lands of Adamawa are the transit zones between sub-Saharan, north and the forest south. The Adamawa Region is one of the ten regions in Cameroon. The Adamawa is a frontier to the Central African Republic to the East and to Nigeria to the west this mountainous zone marks the frontier between the forest south Cameroon and the savanna north. Of a surface area of $64000 \mathrm{~km}^{2}$, Adamawa is the 3th region of Cameroon as concerns the size. It is spread on about $400 \mathrm{~km}$ between Nigeria and the Central African Republic and culminates/reaches its peak at $2460 \mathrm{~m}$ of altitude at the summit of Tchabal Mbabo [25]. Adamawa geographically belong to Sudanese land but the altitude brings in a mountainous difference/variable. That creates conditions of a $\mathrm{n}$ original Sudano-gunean climate characterized by important precipitations, oscillating between 1400 and $2000 \mathrm{~mm}$ per year, low and invariable temperatures (annual average temperature of $23^{\circ} \mathrm{C}$ ), and a strong opposition of two seasons [26] (Figure 1). 


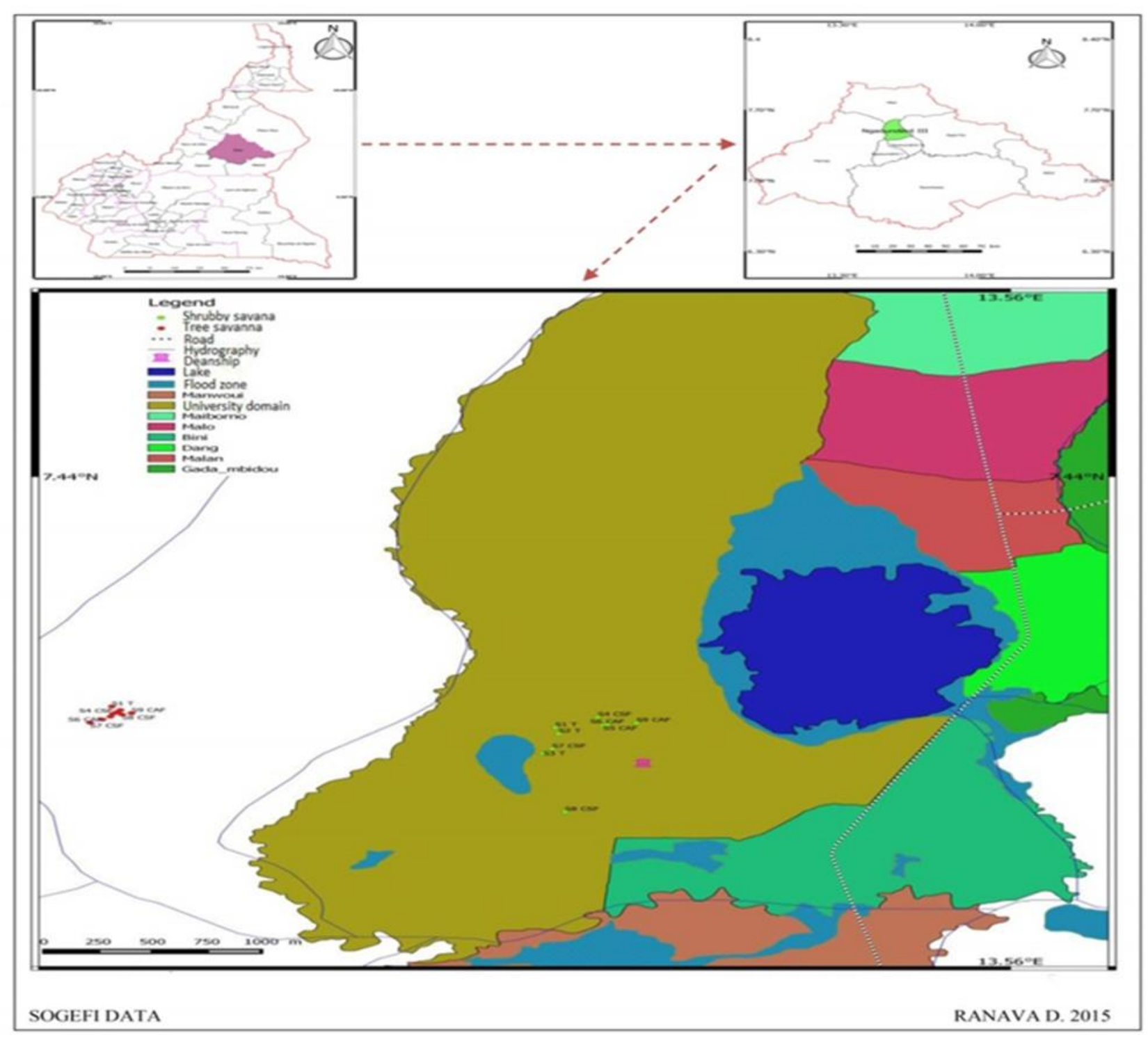

Figure 1 Localization map of the studied area [27]

\subsection{Choice and the presentation of the study area}

The Adamawa region (Cameroon) is subdivided administratively into five (5) divisions: Djerem, Faro and Deo, MayoBanyo, Mbere and Vina. Our study has been carried out in the Vina Division, specifically in the Ngaoundere III $^{\text {th }}$ subdivision in Bini, in two types of savanna (shrub savanna in the vicinity of Deanship of the University of Ngaoundere and in the tree savanna in Dori situated at 5 or $6 \mathrm{~km}$ from Deanship.

\subsection{Method of floristic readings}

The floristic inventory has been carried out by using method of quadra applied with success by [28] and [19] in the Guinean savannas of Adamawa. This method consists in delimiting a surface of $10 \mathrm{~m} \times 10 \mathrm{~m}$ with the help of a decameter within which one carries out measures of dendrometric parameters (height of trees and shrubs, diameters of the tuft, circumference of $0,30 \mathrm{~m}$ and $1,30 \mathrm{~m}$ ) and systematic counting of individuals living and death of ligneous in the trees savannas of BINI and in the shrub savanna of Dori of the Ngaoundere IIIth subdivision. For each of the two vegetations forms, three (3) treatments (felling without fire (CSF), felling with fire (CAF), witness site (T)) have been retained. In each of the treatments, three observations or inventory were done on the potions of $10 \mathrm{~m} \times 10 \mathrm{~m}$, that is a total of eighteen observations accounting for the entire works. These observation or inventories were done/carried out for twelve months on the forms established before. For the herbs, the presence of species has been noted in five layers of $2 \mathrm{~m} \times 10 \mathrm{~m}$ ( 2 meters wide and 10 meters long). The identification of herbs has been carried out systematically on the ground by a botanist. The unidentified species on the ground have been brought back to herbal area of Wakwa for identification. 


\subsection{Methods of calculating parameters}

The different methods of calculating parameters leads to the intervention of the notions of presence, of centesimal frequency of a specie, of specific contribution and of global recovery [29].

\subsubsection{Frequency of ligneous species}

The absolute frequency of the specie (i) is the number of observations accounting this specie. According to [30], relative frequency is the proportion expressed in percentage between the number of observations accounting in this specie and the total number of observations accounting per 100. This method allows determining the accidental, accessory, more frequent, frequent and very frequent species.

\subsubsection{Centesimal frequency (CF) of a given specie}

report of the number of the presence of the specie (NPi) on the total number of points sampled (PE) in percentage. It is calculated following the formula:

$$
\mathrm{FCi}=\frac{\mathrm{NPi}}{\mathrm{PE}} \times 100
$$

\subsubsection{Specific contribution (CSi)}

Report of centesimal frequency (FCi) on the sum of centesimal frequency (FCn) of all the sampled species. It is calculated according to the formula:

$$
\mathrm{CSi}=\frac{\mathrm{FCi}}{\sum \mathrm{niFCn}} \times 100
$$

\subsection{Data Analysis}

Data has been collected, treated and analyzed with the help of the software of Statgraphic plus 17.1.08 software which allows for the comparing of data by site. The parameters such as height, size, presence, enrolment, and number have been subjects analysis of variance (ANOVA). Excel has been used to achieve graphs and histograms, and to calculated percentages, frequency and specific contributions of herbal species.

\section{Results and discussion}

\subsection{Rate of recovery of vegetation according to biological types}

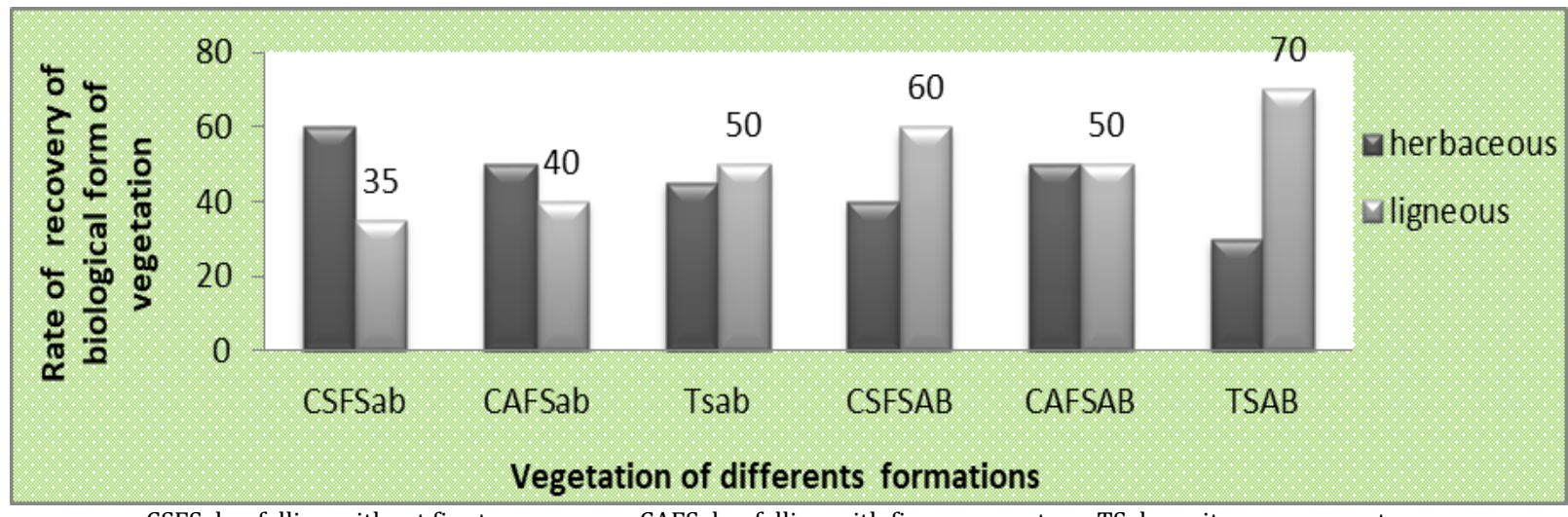

$\mathrm{CSFSab}$ = felling without fire tree savanna; CAFSab = felling with fire savanna tree; TSab = witness savanna tree; CSFSAB = felling without fire savanna shrubs; $\mathrm{CAFSAB}=$ felling with fire savanna shrubs; $\mathrm{TSAB}=$ witness savanna shrubs.

Figure 2 Rate of recovery of biological form of the vegetation of tree and shrub savanna

The rate of recovery of savanna vegetation's is characterized by a very strong presence of ligneous in the shrub savanna (70\% in a witness site, $60 \%$ in the CSF and 50\% in the CAF), but does not differ significantly between treatments ( $\mathrm{p}>$ 0.05). Adversely, in the wood savanna, the herbs are more numerous $60 \%$ in the CSF, $50 \%$ in the CAF and $45 \%$ in witness site). This difference is explained by the fact that in the shrub savanna, there is a domination of trees and shrubs 
whereas in the shrub savanna the herbs dominate followed by shrubs (figure 2). Our results are different from those of [31] on evaluation of the floristic diversity in herbaceous plants in the Manda National Park in Chad who obtained $99.73 \%$ as rate of herbaceous this difference may be due to the difference ecological zone.

\subsection{Evolution of the number of herbs per site and per month}

The evolution of the number of species varies according to months and sites (figure 3). Before the felling and fire (December), we have respectively in the tree savanna 12,15, 11 (CSF, CAF and witness). In the shrub savanna, in the savanna shrub we counted on the contrary, 13, 14 and 16 (CSF, CAF and witness). It shows that there is a significant difference $(\mathrm{p}<0.001)$ treatment in the both savannahs.

In the month of January, the number of specie has reduced in relation to the number before the fire and the wood cutting $(3,5$ and 4$)$ in the tree savannas of 2,2 and 5 respectively in the sites CSF, CAF and witness of shrub trees. As from January until in August, the number of species increase progressively with the time. This may be explained by the rain (started in February in our study area) that stimulated the growth of the plants during the rainy. The season remains an important factor as it characterizes the bush fire regime and its impact on the environment as demonstrated by [32]. The number varies respectively from 3 to 35, from 5 to 43 and from 4 to 32 species in the sites CSF, CAF and witness for the tree savanna. Meanwhile in the shrub savanna the number of species varies respectively from 2 to 31 , from 2 to 34 and from 5 to 22 for the CSF, CAF and witness. Globally the number of species is more elevated in the site CAF. This could already be the action of bushfires which has fostered the propagation of certain herbs. Contrary result has been obtained by [33] in the vegetation in the Sudano-Sahelian zone who had recorded 46 species.

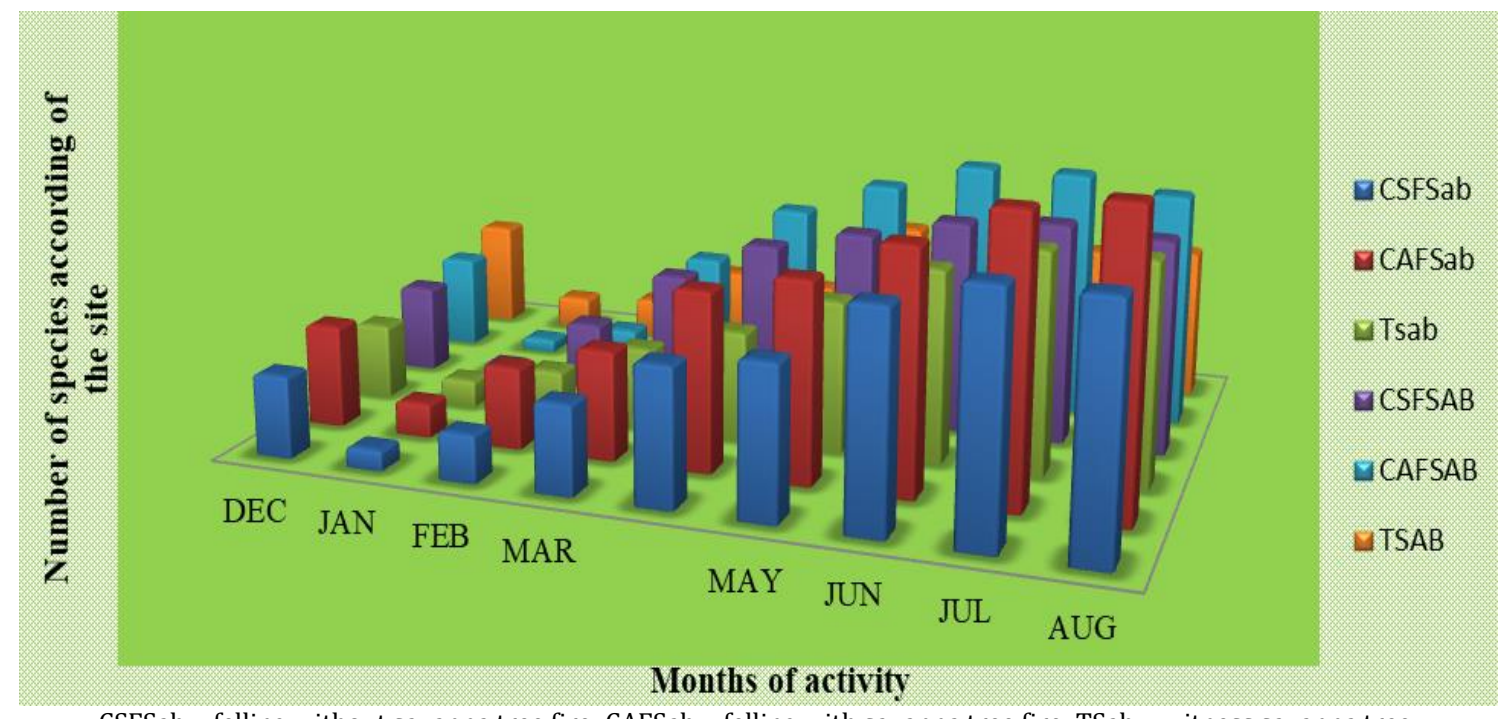

$\mathrm{CSFSab}$ = felling without savanna tree fire; CAFSab = felling with savanna tree fire; TSab = witness savanna tree; $\mathrm{CSFSAB}=$ felling without shrub savanna fire; $\mathrm{CAFSAB}$ = felling with savanna fire shrub; TSAB =witness savanna shrub.

Figure 3 Evolution of the number of herbaceous per month and per site

\subsection{Regrouping of the number of herbs according to the family of the two functions}

As concerns this study, 103 herbs were identified and regrouped into 73 types belonging to 23 families. The number of species varies according to vegetation set up/forms (figure 4).in the shrub savanna, 58 species were sampled in 18 families. The dominating families are the Asteraceae and the Poaceae having 10 species per family that is $20.41 \%$ for each of them, followed by Fabaceae with 07 species per family. That is $14.29 \%$ for a total of $55.11 \%$ as compared to $44.89 \%$ for families poorly represented having 01 to 04 species. The tree savanna presents 20 families for 68 species, the Asteraceae and the Poaceae which dominate with 10 species that is $18.18 \%$ followed by Fabaceae that have 07 species per family pour $14.55 \%$. The dominating families have a percentagee of $50.91 \%$ slightly superior to families that are poorly represented having 01 to 03 species for $1.82 \%$ to $5.45 \%$ that is $49.09 \%$.

The high proportion of Poaceae and Asteraceae in the study area may be due respectively to their competition for light in the open environment and to their ease of dissemination and regrowth. [34] also recorded that Poaceae, Asteraceae and Fabaceae are the the most represented families in the savannah's of Ndikinimeki, Cameroon. Ours result is also lead with those of [35] who found that Poaceae was also the most dominant family in their study area. 


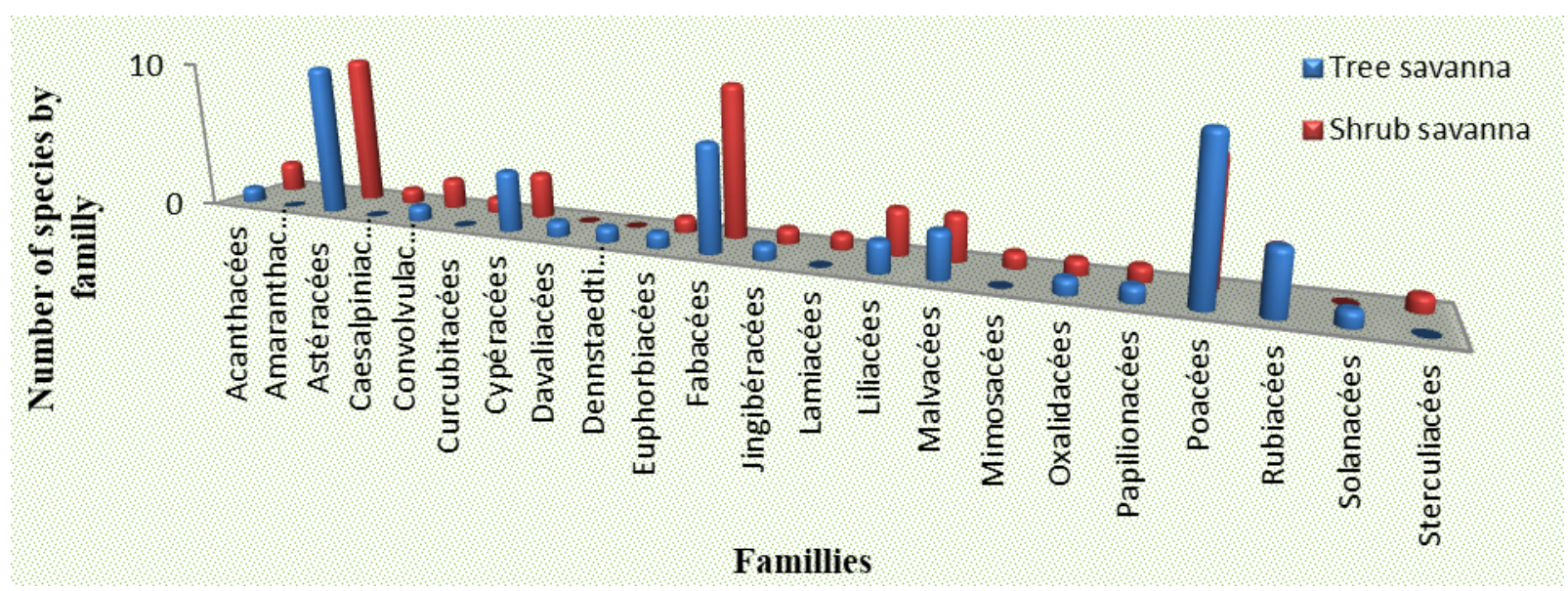

Figure 4 Regrouping herbs by families

\subsection{Regrouping the number of herbs according to botanical families and site}

In this research work, 103 herbaceous were sampled. They belong to 23 families. The number of species varied according to sites (figure 5). However, certain families are present in the savanna arborea and absent in the tree savanna and vice versa.

The family of species presented in the shrub savanna varies by site:

- In CSF 30 species for 13 families: Acanthaceae (01), Asteraceae (05), Cyperaceae (02), Davaliaceae (01), Dennstaedtiaceae (01), Fabaceae (04), Jingiberaceae (02), Liliaceae (01), Malvaceae (03), Papilionaceae (01), Poaceae (06), Rubiaceae (02) et Vitaceae (01);

- In CAF 41 species for 18 families: Acanthaceae (01), Asteraceae (08), Convolvulaceae (02), Cyperaceae (03), Davaliaceae (01), Dennstaedtiaceae (01), Euphorbiaceae (02), Fabaceae (04), Jingiberaceae (02), Liliaceae (01), Malvaceae (03), Oxalidaceae (01), Papilionaceae (01), Poaceae (04), Rubiaceae (04), Solanaceae (01) and Vitaceae (01);

- In the site witness, 24 species for 14 families: Acanthaceae(01), Amaranthaceae(01), Asteraceae (03), Cyperaceae (02), Davaliaceae (01), Dennstaedtiaceae (01), Fabaceae (03), Jingiberaceae (02), Liliaceae (01), Malvaceae (02), Oxalidaceae (01), Poaceae (03), Rubiaceae (02) and Vitaceae (01). The most dominant families are Asteraceae and Poaceae.

The family of species presented in the tree savanna varies by site:

- In CSF of the tree savanna present 41 species for 18 families: Acanthaceae (01), Amaranthaceae (01), Asteraceae (06), Caesalpiniaceae (01), Convolvulaceae (01), Cyperaceae (02), Euphorbiaceae (02), Fabaceae (04), Jingiberaceae (02), Liliaceae (02), Malvaceae (02), Mimosaceae (01), Oxalidaceae (01), Papilionaceae (01), Poaceae (07), Rubiaceae (05), Sterculiaceae (01) and Vitaceae (01);

- In CAF we count 45 species for 17 families: Acanthaceae (01), Amaranthaceae (01), Asteraceae (10), Convolvulaceae (02), Curcubitaceae (01), Cyperaceae (01), Euphorbiaceae (02), Fabaceae (07), Jingiberaceae (02), Lamiaceae (01), Liliaceae (02), Malvaceae (02), Oxalidaceae (01), Poaceae (07), Rubiaceae (03), Sterculiaceae (01) and Vitaceae (01);

- In the witness site 35 species distributed into 13 families: Asteraceae (07), Cyperaceae (03), Euphorbiaceae (01), Fabaceae (04), Jingiberaceae (02), Liliaceae (02), Malvaceae (03), Oxalidaceae (01), Papilionaceae (01), Poaceae (06), Rubiaceae (03), Sterculiaceae (01) and Vitaceae (01). The most dominant families are Asteraceae and Poaceae.

The regrouping of species according to families show that Poaceae and Asteraceae are the most represented in the two savannas. They contribute to the floristic richness of herbaceous. [31] obtained that Poaceae and Fabaceae are dominant, with $39.47 \%$ of specific contribution for the abundant. [28] also found that Astéraceae and the gramineas are very good indices of pastoral value in the vegetation of the Adamawa pastures. 


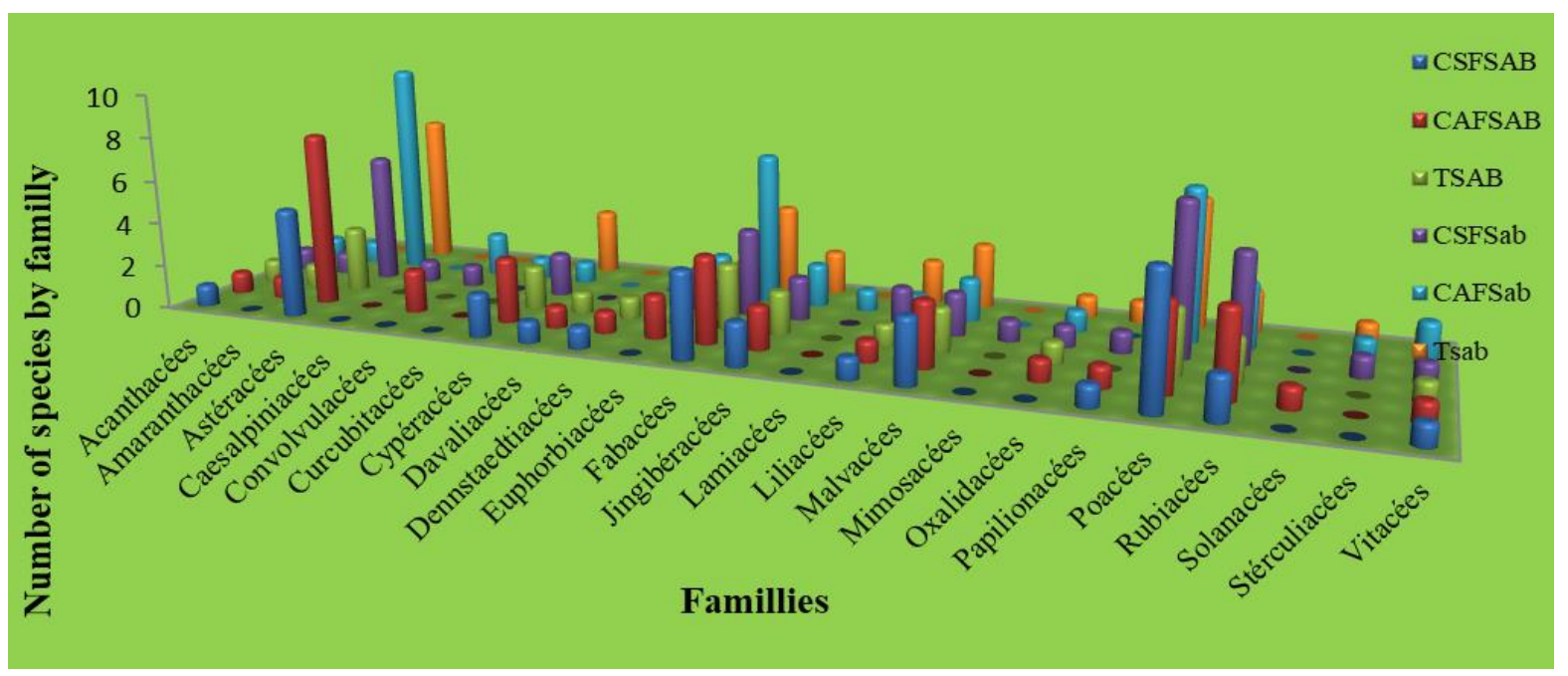

$\mathrm{CSFSab}=$ felling without fire and tree savanna; $\mathrm{CAFSab}=$ felling with savanna tree fire; $\mathrm{TSab}=$ witness tree savanna; $\mathrm{CSFSAB}=$ felling without savanna shrub fire; $\mathrm{CAFSAB}=$ felling with shrub tree fire; $\mathrm{TSAB}=$ witness shrub savanna.

Figure 5 Regrouping the number of herbaceous species per family and site

\subsection{Floristic composition, centesimal frequency and specific contribution of herbaceous species}

In the two types of savanna (shrub and tree), the floristic composition does not differ significantly between treatments. However, there is a clear relation between density, frequency, the dominance of ligneous, the centesimal frequency and the specific contribution of the herbaceous strata. The more the ligneous, the more the specific contribution of herbaceous dominates. The regular the of herbaceous allow recolonization the vegetation.

Table 1 enables us demonstrate the most and least present herbal species. In CSFSab, the species having a Fc from $100 \%$ to $88.89 \%$ for a Cs from $3.04 \%$ to $2.70 \%$ are Eriosema glomeratum, Fadogia cienkowskii, Aframamun latifolia and Chromolaena odorata. For the CAFSab Asparagus schweinfurthii, Crotalaria microphyla, Eriosema glomeratum, to a Fc of 88.89\% for a Cs from 2.74\% are the most present in relation to Biophytum petersionum (0.68\%) from Cs. As for TSab Eriosema glomeratum, Aframamun latifolia, Chromolaena odorata dominates with $100 \%$ and $88.89 \%$ of Fc for $4.41 \%$ and $3.92 \%$ of Cs on $22.22 \%$ of Fc and $0.98 \%$ of Cs for Killinga erecta weakly represented. These results corroborate with those of [36] who showed that the specific contribution ranged from $2.82 \%$ to $3.22 \%$ in 1964 and $4.56 \%$ to $5.78 \%$ in 2011 Case of the CRZ of Dahra. For the CSFAB, the species Asparagus schweinfurthii (100\%) of Fc and 3.93\% of Cs followed by Aframamun latifolia et Chromolaena odorata with $88.89 \%$ of Fc and $3.49 \%$ of Cs which are more represented in connection to Hypoestes cancellata and Mariscus umbellatus having $22.22 \%$ of Fc and $0.87 \%$ of Cs which are not sufficiently represented. The CAFSAB is dominated by Asparagus schweinfurthii,Chromolaena odorata, Crotalaria retusa and Vernonia cinera with $88.89 \%$ of Fc and $2.42 \%$ of Cs on $11.11 \%$ of Fc and $0.30 \%$ of Cs. For Hypoestes cancellata weakly contributable in the TSAB Asparagus schweinfurthii, Chromolaena odorata and Hibiscus asper dominate with $100 \%$ of Fc for $4.62 \%$ of Cs and the least presented species are: Nephrolepis undulata and Loudetia arundinaceae having respectively $33.33 \%$ and $22.22 \%$ of $\mathrm{Fc}$ for $1.54 \%$ and $1.03 \%$ specific contribution. [31] has also obtained in the Manda National Park in Chad 39.47\% as specific contribution from abundant species. The specific contribution elevated of species for certain sites can be due to the recolonization of the vegetation by the herbaceous stratas. 
Table 1 Centesimal frequency and specific contribution

\begin{tabular}{|c|c|c|c|c|c|c|c|c|c|c|c|c|}
\hline \multirow[b]{2}{*}{ Scientific names } & \multicolumn{2}{|c|}{ CSFSab } & \multicolumn{2}{|c|}{ CAFSab } & \multicolumn{2}{|c|}{ TSab } & \multicolumn{2}{|c|}{ CSFSAB } & \multicolumn{2}{|c|}{ CAFSAB } & \multicolumn{2}{|c|}{ TSAB } \\
\hline & Fci & Csi & Fci & Csi & Fci & Csi & Fci & Csi & Fci & Csi & Fci & Csi \\
\hline Aerva javanica & 33.33 & 1.01 & - & - & - & - & - & - & - & - & - & - \\
\hline Aframamum latifolia & 88.89 & 2.70 & 77.78 & 2.40 & 77.78 & 3.43 & 88.89 & 3.49 & 66.67 & 1.82 & 77.78 & 3.59 \\
\hline Alysicarpus nigosus & 22.22 & 0.68 & 33.33 & 1.03 & 22.22 & 0.98 & - & - & - & - & - & - \\
\hline Andropogon gayanus & - & - & - & - & - & - & - & - & 55.56 & 1.52 & - & - \\
\hline Andropogon tectorum & - & - & - & - & - & - & 55.56 & 2.18 & 55.56 & 1.52 & 77.78 & 3.59 \\
\hline Asparagus flagelaris & 55.56 & 1.69 & - & - & 66.67 & 2.94 & - & - & - & - & - & - \\
\hline Asparagus schweinfurthii & 77.78 & 2.36 & 88.89 & 2.74 & 88.89 & 3.92 & 100.00 & 3.93 & 88.89 & 2.42 & 100.00 & 4.62 \\
\hline Aspilia africana & - & - & - & - & - & - & 55.56 & 2.18 & 44.44 & 1.21 & - & - \\
\hline Biophytum petersionum & 33.33 & 1.01 & 22.22 & 0.68 & 33.33 & 1.47 & - & - & 33.33 & 0.91 & 44.44 & 2.05 \\
\hline Blestifum sp. & 66.67 & 2.03 & - & - & - & - & - & - & - & - & - & - \\
\hline Borreria verticillata & 77.78 & 2.36 & 44.44 & 1.37 & 55.56 & 2.45 & 55.56 & 2.18 & 44.44 & 1.21 & 66.67 & 3.08 \\
\hline Brachiaria jubata & 55.56 & 1.69 & - & - & 55.56 & 2.45 & - & - & - & - & - & - \\
\hline Brachiaria lata & 66.67 & 2.03 & 66.67 & 2.05 & 77.78 & 3.43 & 66.67 & 2.62 & 55.56 & 1.52 & - & - \\
\hline Cassia mimosoides & 33.33 & 1.01 & 33.33 & 1.03 & 33.33 & 1.47 & - & - & - & - & - & - \\
\hline Centela asiatica & 44.44 & 1.35 & - & - & 33.33 & 1.47 & 44.44 & 1.75 & 55.56 & 1.52 & - & - \\
\hline Chloris pycnothrix & - & - & 66.67 & 2.05 & - & - & - & - & - & - & - & - \\
\hline Chromolaena odorata & 88.89 & 2.70 & - & - & 88.89 & 3.92 & 88.89 & 3.49 & 88.89 & 2.42 & 100.00 & 4.62 \\
\hline Chrysanthellum americanum & 22.22 & 0.68 & 33.33 & 1.03 & 33.33 & 1.47 & - & - & 44.44 & 1.21 & - & - \\
\hline Cissus rubigirosa & 88.89 & 2.70 & 77.78 & 2.40 & 88.89 & 3.92 & 77.78 & 3.06 & 77.78 & 2.12 & 77.78 & 3.59 \\
\hline Cornea sp. & 33.33 & 1.01 & 77.78 & 2.40 & - & - & - & - & 66.67 & 1.82 & - & - \\
\hline Costus englerianus & 44.44 & 1.35 & 66.67 & 2.05 & 33.33 & 1.47 & 66.67 & 2.62 & 88.89 & 2.42 & - & - \\
\hline Crotalaria gorensis & 66.67 & 2.03 & 33.33 & 1.03 & - & - & - & - & - & - & - & - \\
\hline Crotalaria microphyla & - & - & 88.89 & 2.74 & - & - & - & - & - & - & - & - \\
\hline
\end{tabular}


World Journal of Advanced Research and Reviews, 2021, 10(03), 334-347

\begin{tabular}{|c|c|c|c|c|c|c|c|c|c|c|c|c|}
\hline Crotalaria retusa & 66.67 & 2.03 & 77.78 & 2.40 & 33.33 & 1.47 & 44.44 & 1.75 & 88.89 & 2.42 & 44.44 & 2.05 \\
\hline Cyathula prostrata & - & - & - & - & - & - & 55.56 & 2.18 & 33.33 & 0.91 & - & - \\
\hline Cyphostemina leucotrichum & - & - & 33.33 & 1.03 & 33.33 & 1.47 & - & - & - & - & - & - \\
\hline Desmodium salicifolium & - & - & - & - & - & - & - & - & 44.44 & 1.21 & 44.44 & 2.05 \\
\hline Desmodium tortuosum & - & - & 66.67 & 2.05 & 44.44 & 1.96 & - & - & - & - & - & - \\
\hline Dicrocephala integrifolia & 33.33 & 1.01 & - & - & - & - & - & - & - & - & - & - \\
\hline Erioséma glomératum & 100.00 & 3.04 & 88.89 & 2.74 & 100.00 & 4.41 & 77.78 & 3.06 & 77.78 & 2.12 & 66.67 & 3.08 \\
\hline Emilia coccinea & 77.78 & 2.36 & - & - & - & - & - & - & - & - & - & - \\
\hline Eragrostis atrovirens & 55.56 & 1.69 & - & - & - & - & - & - & - & - & - & - \\
\hline Eragrostis turgida & 22.22 & 0.68 & 33.33 & 1.03 & - & - & - & - & - & - & - & - \\
\hline Erigeron floribundus & 22.22 & 0.68 & 33.33 & 1.03 & 33.33 & 1.47 & - & - & - & - & - & - \\
\hline Euphorbia foscalii & - & - & - & - & - & - & - & - & 44.44 & 1.21 & - & - \\
\hline Fadogia cienkowskii & 100.00 & 3.04 & - & - & - & - & - & - & 55.56 & 1.52 & - & - \\
\hline Fadogia glaberrima & - & - & - & - & - & - & 77.78 & 3.06 & 66.67 & 1.82 & - & - \\
\hline Fadogia ledermanii & 77.78 & 2.36 & - & - & - & - & - & - & 55.56 & 1.52 & - & - \\
\hline Gomphera celosioides & - & - & 33.33 & 1.03 & - & - & - & - & - & - & - & \\
\hline Hibiscus asper & - & - & - & - & - & - & 55.56 & 2.18 & 66.67 & 1.82 & 100.00 & 4.62 \\
\hline Hyparrhenia rufa & 77.78 & 2.36 & 66.67 & 2.05 & 77.78 & 3.43 & 77.78 & 3.06 & 66.67 & 1.82 & 77.78 & 3.59 \\
\hline Hypoestes cancellata & 33.33 & 1.01 & - & - & - & - & 22.22 & 0.87 & 11.11 & 0.30 & 55.56 & 2.56 \\
\hline Hyptis lenceolata & - & - & 33.33 & 1.03 & - & - & - & - & - & - & - & - \\
\hline ind 1 & 44.44 & 1.35 & 33.33 & 1.03 & - & - & - & - & 66.67 & 1.82 & - & - \\
\hline ind 2 & - & - & 22.22 & 0.68 & 33.33 & 1.47 & - & - & - & - & - & - \\
\hline ind 3 & - & - & 77.78 & 2.40 & - & - & - & - & - & - & - & - \\
\hline ind 4 & - & - & 66.67 & 2.05 & 88.89 & 3.92 & - & - & 66.67 & 1.82 & - & - \\
\hline ind 5 & - & - & 77.78 & 2.40 & 88.89 & 3.92 & - & - & 66.67 & 1.82 & - & - \\
\hline ind 6 & - & - & 77.78 & 2.40 & 33.33 & 1.47 & - & - & - & - & - & - \\
\hline Ind 7 & 22.22 & 0.68 & - & - & 22.22 & 0.98 & 22.22 & 0.87 & - & - & - & - \\
\hline
\end{tabular}


World Journal of Advanced Research and Reviews, 2021, 10(03), 334-347

\begin{tabular}{|c|c|c|c|c|c|c|c|c|c|c|c|c|}
\hline Indigofera hirsuta & - & - & 77.78 & 2.40 & 33.33 & 1.47 & - & - & 77.78 & 2.12 & - & - \\
\hline Indigofera nummelariifolia & 33.33 & 1.01 & - & - & - & - & 33.33 & 1.31 & 44.44 & 1.21 & - & - \\
\hline Indigofera tentolia & 33.33 & 1.01 & 33.33 & 1.03 & 44.44 & 1.96 & - & - & - & - & 44.44 & 2.05 \\
\hline Ipomea aquatica & 33.33 & 1.01 & 33.33 & 1.03 & - & - & - & - & 44.44 & 1.21 & - & - \\
\hline Ipomea sp. & 22.22 & 0.68 & - & - & 33.33 & 1.47 & - & - & - & - & - & - \\
\hline Killinga erecta & 22.22 & 0.68 & - & - & 22.22 & 0.98 & - & - & 44.44 & 1.21 & - & - \\
\hline Killinga squamosa & - & - & - & - & - & - & 33.33 & 1.31 & - & - & - & - \\
\hline Launnea cormuta & 77.78 & 2.36 & 66.67 & 2.05 & - & - & 66.67 & 2.62 & 66.67 & 1.82 & 44.44 & 2.05 \\
\hline Lipia sp. & - & - & - & - & - & - & 44.44 & 1.75 & - & - & - & - \\
\hline Loudetia arundinaceae & - & - & - & - & - & - & - & - & - & - & 22.22 & 1.03 \\
\hline Mariscus squarrosus & - & - & 77.78 & 2.40 & - & - & 77.78 & 3.06 & 66.67 & 1.82 & 77.78 & 3.59 \\
\hline Mariscus umbellatus & 55.56 & 1.69 & - & - & - & - & 22.22 & 0.87 & 55.56 & 1.52 & - & - \\
\hline Merrenia tridentata & - & - & 88.89 & 2.74 & - & - & - & - & 55.56 & 1.52 & - & - \\
\hline Mimosa pudica & 77.78 & 2.36 & - & - & 55.56 & 2.45 & - & - & - & - & - & - \\
\hline Momordica charantia & - & - & 55.56 & 1.71 & - & - & - & - & - & - & - & - \\
\hline Monechma ciliatum & - & - & 66.67 & 2.05 & - & - & - & - & - & - & - & - \\
\hline Musa sp. & - & - & - & - & - & - & 44.44 & 1.75 & 55.56 & 1.52 & - & - \\
\hline Nephrolepis undulata & - & - & - & - & - & - & 44.44 & 1.75 & 44.44 & 1.21 & 33.33 & 1.54 \\
\hline Oldenlandia corymbosa & 33.33 & 1.01 & 33.33 & 1.03 & - & - & - & - & - & - & - & - \\
\hline Oldenlandia corymbosa & - & - & - & - & - & - & - & - & 55.56 & 1.52 & 55.56 & 2.56 \\
\hline Panicum maximum & - & - & - & - & - & - & - & - & 55.56 & 1.52 & 55.56 & 2.56 \\
\hline Panicum repens & - & - & - & - & - & - & - & - & 55.56 & 1.52 & - & - \\
\hline Pennicetum pedicellatum & 66.67 & 2.03 & 55.56 & 1.71 & 55.56 & 2.45 & 44.44 & 1.75 & - & - & 77.78 & 3.59 \\
\hline Pennicetum polystachion & 66.67 & 2.03 & 55.56 & 1.71 & 55.56 & 2.45 & 55.56 & 2.18 & 77.78 & 2.12 & 66.67 & 3.08 \\
\hline Phyllanthus amarus & 33.33 & 1.01 & 22.22 & 0.68 & 33.33 & 1.47 & - & - & 33.33 & 0.91 & - & - \\
\hline Pseudarthria hookeri & 77.78 & 2.36 & - & - & - & - & 77.78 & 3.06 & 77.78 & 2.12 & - & - \\
\hline Pteridium aquilinum & - & - & - & - & - & - & 44.44 & 1.75 & 44.44 & 1.21 & 44.44 & 2.05 \\
\hline
\end{tabular}


World Journal of Advanced Research and Reviews, 2021, 10(03), 334-347

\begin{tabular}{|c|c|c|c|c|c|c|c|c|c|c|c|c|}
\hline Rhynchosia nyasica & - & - & 33.33 & 1.03 & - & - & - & - & - & - & - & - \\
\hline Rhynchospora corymbosa & - & - & - & - & - & - & 66.67 & 2.62 & 77.78 & 2.12 & 55.56 & 2.56 \\
\hline Schweinkia américana & - & - & - & - & - & - & - & - & 44.44 & 1.21 & - & - \\
\hline Scripus jacobi & 22.22 & 0.68 & - & - & 44.44 & 1.96 & - & - & - & - & - & - \\
\hline Sena torra & 55.56 & 1.69 & - & - & 33.33 & 1.47 & - & - & - & - & - & - \\
\hline Setaria pumila & - & - & 33.33 & 1.03 & - & - & - & - & - & - & - & - \\
\hline Sida corymbosa & 66.67 & 2.03 & 66.67 & 2.05 & - & - & 66.67 & 2.62 & 55.56 & 1.52 & - & - \\
\hline Sida rhombifolia & 66.67 & 2.03 & 66.67 & 2.05 & - & - & 77.78 & 3.06 & 77.78 & 2.12 & 66.67 & 3.08 \\
\hline Spermacoce stachydea & 33.33 & 1.01 & 33.33 & 1.03 & - & - & - & - & - & - & - & - \\
\hline Sporobolis pyramidalis & 55.56 & 1.69 & 55.56 & 1.71 & 77.78 & 3.43 & 44.44 & 1.75 & 44.44 & 1.21 & - & - \\
\hline Stylosanthes guanensis & 44.44 & 1.35 & - & - & 55.56 & 2.45 & 77.78 & 3.06 & 77.78 & 2.12 & 77.78 & 3.59 \\
\hline Teramnus labialis & 44.44 & 1.35 & 55.56 & 1.71 & - & - & 55.56 & 2.18 & 66.67 & 1.82 & 77.78 & 3.59 \\
\hline Tithonia diversifolia & - & - & 66.67 & 2.05 & 77.78 & 3.43 & - & - & - & - & - & - \\
\hline Trifolium sp. & 66.67 & 2.03 & - & - & 44.44 & 1.96 & 77.78 & 3.06 & 77.78 & 2.12 & 66.67 & 3.08 \\
\hline Urena lobata & 66.67 & 2.03 & - & - & 66.67 & 2.94 & 55.56 & 2.18 & 66.67 & 1.82 & 55.56 & 2.56 \\
\hline Vernonia cinera & - & - & - & - & - & - & 77.78 & 3.06 & 88.89 & 2.42 & 77.78 & 3.59 \\
\hline Vernonia colorata & - & - & 66.67 & 2.05 & - & - & 66.67 & 2.62 & 66.67 & 1.82 & 66.67 & 3.08 \\
\hline Vernonia glaberrima & - & - & 77.78 & 2.40 & 33.33 & 1.47 & - & - & - & - & - & - \\
\hline Vernonia nestor & - & - & 33.33 & 1.03 & 33.33 & 1.47 & - & - & - & - & - & - \\
\hline Vernonia perrottetii & 44.44 & 1.35 & 44.44 & 1.37 & - & - & 33.33 & 1.31 & 44.44 & 1.21 & 88.89 & 4.10 \\
\hline Walthiria indica & 66.67 & 2.03 & 66.67 & 2.05 & 44.44 & 1.96 & - & - & - & - & - & - \\
\hline Wilwichia sp. & - & - & - & - & - & - & - & - & 88.89 & 2.42 & - & - \\
\hline Zornia glochidiata & 77.78 & 2.36 & 55.56 & 1.71 & - & - & - & - & - & - & - & - \\
\hline Zornia latifolia & 44.44 & 1.35 & 77.78 & 2.40 & 44.44 & 1.96 & - & - & - & - & - & - \\
\hline
\end{tabular}

CSFSab =felling without savanna tree fire; CAFSab = felling with savanna tree fire; TSab =witness savanna tree; CSFSAB = felling without savanna shrub fire;

$\mathrm{CAFSAB}=$ felling with savanna shrub fire; $\mathrm{TSAB}=$ witness shrub savanna; $\mathrm{Fc}=$ centesimal frequency and $\mathrm{Cs}=$ specific contribution 


\subsection{Impact of wood cutting and of bushfires on the distribution of herbs}

Figure 6 shows that in the tree savanna the accidental species are more represented more by the very frequent species. The accidental species (Emilia coccinea, Scrorpus jacobi, Ipomea aquatica); accessories (Kyllinga squamulata, Cassia mimisoides, Erigeron floribundus); more frequent (Mariscusalternifolius, Teramnus labialis, Pennisetum sp.); frequent (Brachiaria lata, Hyparhenia rufa, Sida rhombifolia); very frequent (Eriosema glomeratum, Aframamum latifolia, Asparagus flagelaris) are observed in figure 6a: These results corroborate that of [37] who found that the dominant species to be: accidental, accessories, more frequent and frequent. Meanwhile, in the shrub savanna the species having a representative frequency are the accidental (Cornea sp. Indigofera mumelarifolia, Oldenlandia corymbosa) followed by more frequent species (Borreria verticilata, Pteridium aquilinum, Centela asiatica) in the CAF. The accessories species are Hypoetes cancelata, Loudetia arundinacea and Biophytum petersionum. For frequent species we have Stylosanthes guanensis, Vernonia cinera, Trifolium sp and for very frequent we: Asparagus schweinfurthii; Chromoleana odorata; Vernonia colorata (Figure 6b). The disappearance or the rareness of certain herbal species in an area is due to bush fires which burn diaspores and the grains in the soil. [34] also the regression of species in the burning savannah's Ndikinimeki due to the presence of bush fire which limits the growth and development of certain species. These result means that bush fire reduces the specific richness.

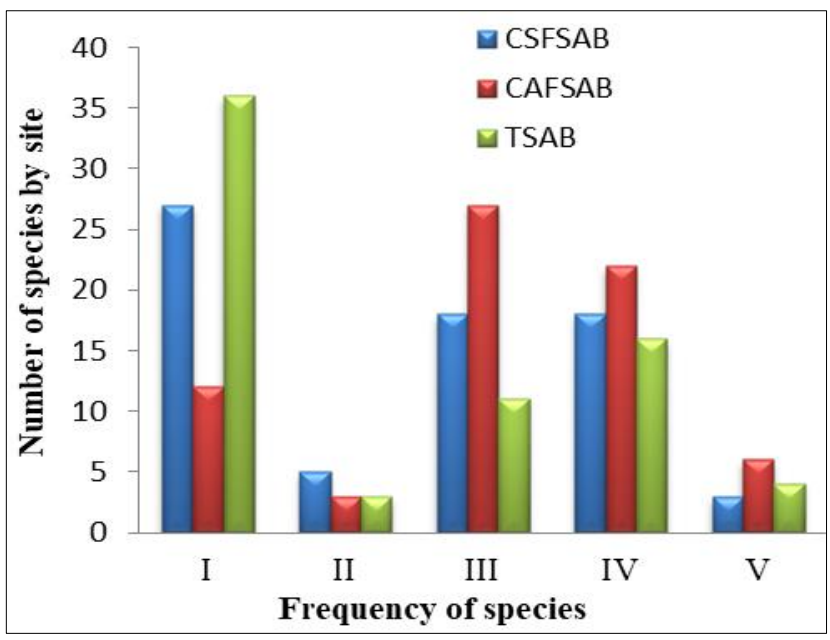

Figure 6a Frequency indice of in the tree savanna

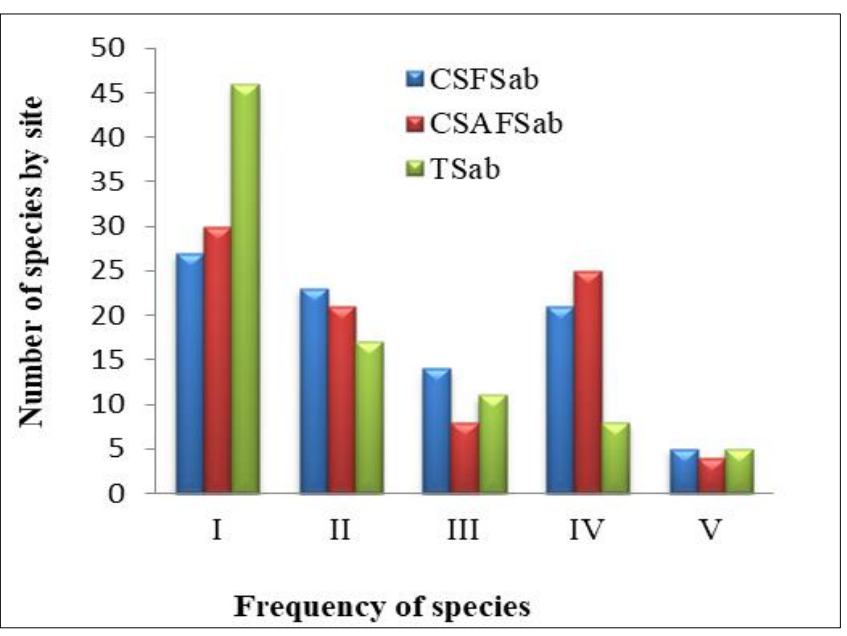

Figure 6b Frequency indice of shrub savanna

$\mathrm{CSFSab}=$ felling without savanna tree fire; CAFSab = felling with savanna tree fire; $\mathrm{TSab}=$ witness savanna tree; $\mathrm{CSFSAB}$ = felling without savanna shrub fire; $\mathrm{CAFSAB}=$ felling with savanna shrub fire; $\mathrm{TSAB}=$ witness savanna shrub

Figure 6 Frequency indice of herbal species

\section{Conclusion}

The research study on the impact of the complex wood felling and bushfire on the dynamics of the regeneration herbaceous of the sudano-guinean vegetations has evaluated the recovery of the vegetation of shrub and grass savanna, knowed the evolution of the number of herbs according to time, done the regroupings of herbal species in the different vegetation formations and at last and determined the floristic composition, the centesimal frequency and the specific contribution of the herbal specie. The result showed that the shrub savanna has 103 herbal species sampled in 73 types belonging to 23 families, 58 species for 18 families in the shrub savanna and 68 species for 20 families in the tree savanna. The floristic richness of herbs in the savannas is dominated by certain families: Poaceae (10 species); Fabaceae (10 species); Asteraceae (10 species); followed by Malvaceae and Rubiaceae (4 species). The specific contribution elevated of species for certain sites can be due to the recolonization of the vegetation by the herbacea stratas. It is advisable to use the controlled method of felling trees without fire for a natural regeneration and a lasting management of resources while avoiding the repeated felling of trees every year on the same potion of land. 


\section{Compliance with ethical standards}

\section{Acknowledgments}

We thank the local population of the Ngaoundere III ${ }^{\text {th }}$ Sub division for their individual participation in this research work.

\section{Disclosure of conflict of interest}

There is no conflict of interest.

\section{References}

[1] Auroi C. Biodiversity. Life at risk. Collection «environment tol file», Swiss society for the protection environment. 1992; 37.

[2] Wilson EO, Peter FM. Biodiversity. National academy press, Washington DC, Etats-Unis. 1988 ; 9.

[3] Ibrahima A, Schmidt P, Ketner P. Plant biomass and nutrient cycling in there dense humid tropical forest of southern Cameroon. The Tropenbos-Cameroon Programme, Kribi, Cameroon. 2002; 33.

[4] Anonymous. The importance of biodiversity and transformation of the physical environment. $2015 ; 2$.

[5] Peltier R, Njiti F, Ntoupka M. Carbon stock assessment and wooden reproduction of Shea park northeastern Cameroon, wood tropical Forets. 2007; 294(4): 16-50.

[6] Dogmo. Floristic and ethno-botanical studies in a village in the forest zone of Cameroon: Master thesis, University of Yaoundé I, Cameroon. 2002; 72.

[7] Walker BH, Noy MI. Aspects of the stability and resilience of savanna ecosystems. In Huntley B.J. \& Walker B.H. (Eds.), Ecology of tropical savannas. Ecological studies. 1982; 42.

[8] Gignoux J, Menaut JC, Noble IR, Davies ID. A spatial model of savanna function and dynamics: model description and preliminary results. Population and community dynamics in the tropics. 1997; 361.

[9] Jeltsch F, Weber GE, Grimm V. Ecological buffering mechanisms in savannas: a unifying theory of long-term treegrass coexistence. Plant Ecology. 2000; 161.

[10] FAO. Report on the world's soil resource. 2002; 96.

[11] Bellefontaine R, Petit S, Pain-Orcet M. Trees outside forest towards a better consideration. FAO document repository departments of forests. Paris. 2001; 16.

[12] Degrande A, Essomba H, Bikoue MC. Domestication, gender and vulnerability. Participation of women, youth and the poorest to the domestication of agroforestry trees in Cameroon. ICRAF Working Paper No. 48. Yaounde, ICRAF-WCA/HT. 2007; 45.

[13] Mapongmetsem PM, Nkongmeneck BA, Rongoumi G, Dongock D, Dongmo B. Impact of land use on the shelf Vitellaria paradoxa gaertn. f. (Sapotaceae) in the region of the sudan Guinean savannas. International journal of environmental studies. 2011; 68(6): 51.

[14] Reynolds JF, Maestre FT, Kemp PR, Stafford-Smith DM, Lambin E. Natural and Human Dimensions of Land Degradation in Drylands: Causes and Consequences. In Canadell J.G., Pataki D.E. \& Pitelka L.F. (Eds.), Terrestrial Ecosystems in a Changing World. 2007; 247.

[15] Sere C. Charactersation and quantification of livestock production systems. In FAO/OPHD (Ed.). Rome: FAO. 1994; 13.

[16] Ancey V. (1996) Economic trajectories of pastoral livestock: livestock farmers in northern of is very of Ivory coast. In. Paris: High school studies in social Sciences. 1996; 137.

[17] Boutonnet JP, Griffon M, Viallet D. Competitiveness of livestock production in sub-saharan and Madagascar. In DGCID (Ed.). 2001; 191.

[18] Louppe D, Ouattara N, Coulibaly A. Effects of bush fire on vegetation. wood and tropical forest. 1995; 245: 59-69. 
[19] Tchobsala. Impact of wood logging on the natural vegetation of the suburban area of Ngaoundere (Adamaoua). $\mathrm{PhD}$ thesis, University of Yaounde I, Cameroun. 2011; 204.

[20] Ntoupka M. Impact of the management of organic light on the mineral status of soil and corps in Soudan savanna pitched a born Ngaoundere, Cameroon. 1994; 6.

[21] Ndam N. Tree regeneration, vegetation dynamics and the maintenance of biodiversity on Mount Cameroon: the relative impact of natural and human disturbance. Thesis, University of Wales, Bangor, UK. 1998; 278.

[22] Faye EH. Dynamic of woody regeneration during the growing phase in a semi-continuous culture system in southem Senegal. Conference May 2002. 27-31.

[23] Pamo TE, Yonkeu S. Study of the evolution of some climate settings of the pastoral environment of Wakwa, Adamawa-Cameroon. Rev. Sci. Techn. 1986; 2(3): 19.

[24] Bring. Variability and evolution of annual precipitation on the 'Adamawa. Tray. Fac. Arts Lett. Sci. Hum. Univ. Ngaoundere. 1999; 4: 47.

[25] Tchotsoua M, Gonne B. Socio-economic crises to environmental crises in the highlands Adamawa region, Cameroon. 2010; 1.

[26] Boutrais J. Sudarian bree ding (Cameroon, Nigeria). Paris, ORSTOM Editions. 1983; 147.

[27] Ranava. The study site location figure. SOGEFI data base. 2015.

[28] Yonkeu S. Pastures vegetation of Adamawa (Cameroon). Ecology and potential pastoral. Ph.D thesis (Biological Sciences). Univ. Rennes I. France. 1993; 207.

[29] Daget P, Poissonnet J. Aphytosociological analysis of grassland. Ann. Agron., INRA, Paris. 1972; 22(1): 32- 41.

[30] Braun-blanquet. Plant sociology. The study of plant communities. Mcgray Hill. New-York. Londres. 1932; 439.

[31] Ndotam TI, Reounodji F, Lumande KJ, Diaouangana J. Evaluation of the floristic diversity in herbs in the Manda National Park in Chad. Int. J. Biol. Chem. Sci. 2017; 11(4): 1484 -1496.

[32] Martin RE, Sapsis DB. Fires as agents of biodiversity: pyrodiversity promotes biodiversity. In Proc. of the Symp. on Biodiversity in Northwestern California, (ed. Kerner HM.), Berkeley, CA: Wildland Resources Centre, University of California. 1991-1992; 150-157.

[33] Haiwa G. Impact of deforestation on vegetation dynamics in the Sudano-Sahelian zone (case of the Far North region, Cameroon). Ph.D. thesis, University of Ngaoundere, Cameroon. 2018; 79-186.

[34] Tchoupou MCV, Nkengbeza NS, Tetchieu GI, Maffo MNL, Dongmo DZ, Tagnang MN, Djomo CC, Kabelong BRPL, Essono D, Ngansop TM, Mounmemi KH, Kenmougne MP, Ntonmen YFA, Leukefack A, Zapfack L. Impact of Bush Fire and Grazing on the Diversity of Herbaceous Plants in the Savannah's Zones of the Ndikinimeki District Central Cameroon. Asian Journal of Research in Biosciences. 2021; 3(2): 21-32.

[35] Assédé EPS, Adomou AC, Sinsin B. Magnoliophyta, biosphere reserve of Pendjari, atacora province, Benin. Check List. 2012; 8(4): 642-661.

[36] Ndiaye 0, Tamsir DA, Diène M, Akpo LE. Comparative study of the vegetation of 1964 and 2011 in a grazed environment: Case of the CRZ of Dahra. J. Appl. Biosci. 2015; 88: 8235-8248.

[37] Ranava D. Impact of logging and bushfires on vegetation regeneration dynamics and carbon stock in the high humid savannah zone (Adamaoua Cameroon). Ph.D. thesis, University of Ngaoundere, Cameroon. 2020; 146-148. 